\title{
KEPADATAN DAN POLA DISTRIBUSI KERANG KIMA (Tridacnidae) DI PERAIRAN TELUK NITANGHAHAI DESA MORELLA MALUKU TENGAH
}

\author{
Inem Ode * \\ Staf Pengajar FPIK UNIDAR - Ambon, Email: odeinem@gmail.com
}

\begin{abstract}
ABSTRAK
Penelitian ini bertujuan untuk mengetahui kepadatan dan pola distribusi kerang kima (Tridacnidae) di Perairan Teluk Nitanghahai Desa Morella Maluku Tengah. Penelitian ini dilakukan pada bulan Agustus 2017. Penelitian ini menggunakan metode belt transek. Hasil penelitian menemukan 5 jenis kima, yaitu Tridacna squamosa, Tridacna maxima, Tridacna maxima, Tridacna gigas dan Hipoppus hipoppus. Kelimpahan relatif individu tertinggi pada Tridacna squamosa sebesar $38,54 \%$ dan terendah Hipoppus hipoppus sebesar $0,52 \%$. Kepadatan individu tertinggi pada Tridacna crocea sebesar 0.048 dan terendah pada Tridacna gigasyaitu 0.0013. Terdapat tiga pola distribusi kima di lokasi penelitian, yaitu pola distribusi mengelompok pada jenisTridacna sqoamosa, Tridacnacrocea, dan Tridacna maxima. Pola distribusi acak pada jenis Tridacna gigas dan pola distribusi seragam pada jenis Hipoppus hipoppus.
\end{abstract}

Kata Kunci : Kima, kepadatan, pola distribusi

\section{PENDAHULUAN}

1.1. Latar Belakang

Perairan teluk Nitanghahai di desa Morella, Kabupaten Maluku Tengah saat ini telah dikembangkan untuk kegiatan ekowisata pantai. Perairan ini memiliki substrat dasar perairan terdiri dari pasir, pecahan karang mati dan terumbu karang. Salah satu biota yang paling banyak ditemukan di ekosistem terumbu karang perairan ini adalah kerang Kima.

Kima atau kerang raksasa (Giant Clam), merupakan salah satu jenis bivalvia yang sering ditemukan pada perairan ekosistem karang. Kima hidup berasosiasi dengan terumbu karang dengan cara menenggelamkan diri pada substrat (mengebor), serta memiliki pigmen pada mantel yang berasal dari asosiasinya dengan alga (Niartiningsih, 2012). Hewan ini memiliki dua genera (Tridacna dan Hippopus) dengan sembilan spesies, di mana tujuh spesies di antaranya ditemukan di perairan Indonesia. Secara geografis, kerang ini memiliki distribusi terbatas di wilayah tropis Indo-Pasifik, dari Red Sea sampai ke
Kepulauan Pasifik Tuamotu (Yusuf et al., 2009). Dari segi ekologis kerang kima merupakan biota yang berperan sebagai biofilter alami, di mana mereka mampu menyaring amonia dan nitrat terlarut dalam air laut untuk kebutuhan zooxanthellae akan nitrogen bagi proses pertumbuhannya (Betay 2012).

Kerang kima dikenal memiliki nilai ekonomi yang penting karena selain sebagai sumber makanan, cangkangnya dapat dijadikan sebagai bahan dekorasi dan perhiasan. Selain itu juga, kerang ini banyak dicari orang untuk perhiasan serta untuk industri ubin teraso, sehingga populasinya makin berkurang (Nontji, 2002). Permintaan terhadap kima (Tridacnidae) sebagai sumber protein hewani sampai saat ini terus meningkat, sehingga populasinya di alam menurun drastis hampir di seluruh dunia akibat pengambilan tanpa batas, termasuk juga di Indonesia. Pada tahun 1987 pemerintah Indonesia melalui Surat Keputusan Menteri Kehutanan No. 12/Kpts/II/1987 yang diperkuat dengan Peraturan Pemerintah No. 7 Tahun 1999 memasukkan ketujuh jenis kima yang hidup di 
Indonesia menjadi hewan yang dilindungi.

Penetapan tersebut berdasarkan kenyataan bahwa populasi kima di alam sudah sangat menurun terutama disebabkan oleh pemanfaatan manusia.

Menurut Rani (2003) Pola sebaran organisme adalah karakter penting dalam ekologi komunitas. Ini biasanya yang pertama kali diamati dalam melihat beberapa komunitas dan salah satu sifat dasar dari kebanyakan kelompok organisme hidup. Dua populasi mungkin saja memiliki kepadatan yang sama, tetapi mempunyai perbedaan yang nyata dalam pola sebaran spasialnya.

Dengan dikembangkannya teluk Nitanghahai desa Morella sebagai daerah ekowisata maka perlu dilakukan penelitian tentang kepadatan dan pola distribusi kima di lokasi ini sebagai data dasar untuk pengembangan konservasi kima dan sebagai bahan evaluasi bagi pengelolaan ekowisata.

\subsection{Tujuan Penelitian}

Penelitian ini bertujuan untuk mengetahui kepadatan dan pola distribusi kerang kima (Tridacnidae ) di Perairan Teluk Nitanghahai desa Morella, Maluku Tengah.

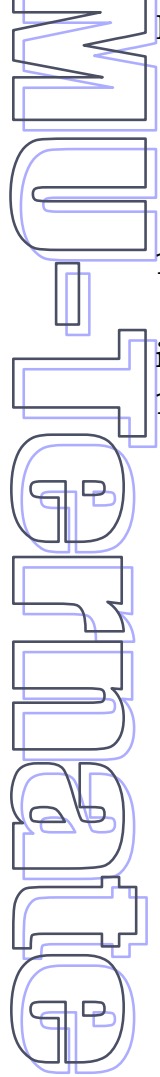

2. Sebagai bahan evaluasi kepada pengelola ekowisata untuk pengelolaan ekowisata secara berkelanjutan dengan tidak merusak ekosistem terumbu karang yang merupakan habitat kima

\section{Metode Penelitian}

\subsection{Waktu dan Lokasi Penelitian}

Penelitian ini dilaksanakan pada bulan Agustus 2017 yang berlokasi di Perairan Teluk Nitanghahai Desa Morella, Maluku Tengah (Gamba 1).

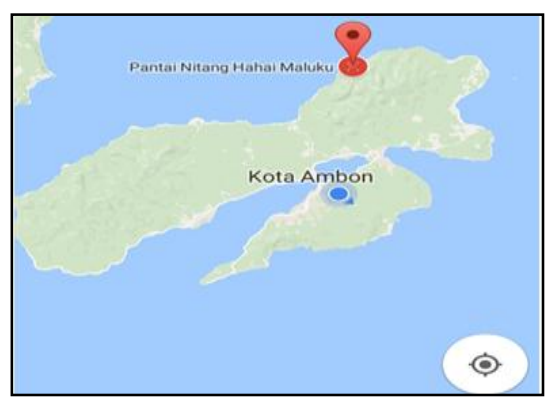

Gambar 1. Peta lokasi penelitian

\subsection{Pengambilan Sampel}

Pengambilan sampel kima menggunakan metode belt transek sebanyak empat transek dengan jarak antar transek $25 \mathrm{~m}$, pada tiap taransek di pasang kuadran berukuran $10 \times 10$ m. Jenis kima yang ditemukan dihitung dan diidentifikasi berdasarkan morfologi cangkang dengan mengacu pada CITES Management Authority Australia in litt, (2005). Selama pengambilan sampel juga dilakukan pengukuran parameter kualiatas air yang terdiri dari suhu, salinitas dan $\mathrm{pH}$. Desain belt transek dapat di lihat pada Gambar 2.

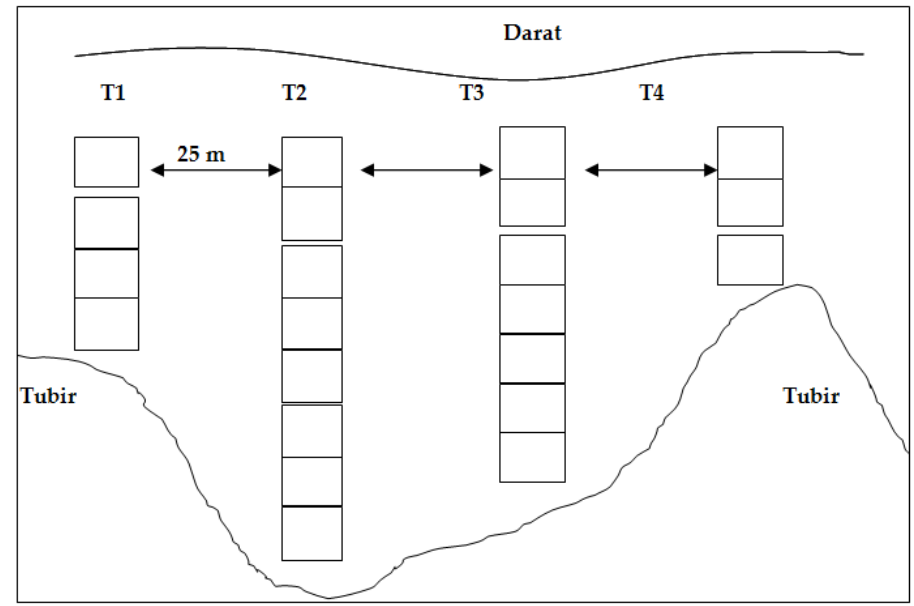

Gambar 2. Desain belt transek 
2.3. Analisis Data

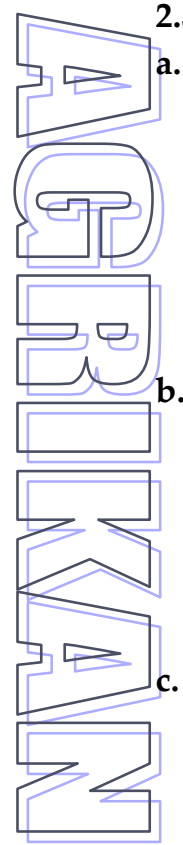

a. Kelimpahan Relatif dihitung dengan formula

$\mathrm{KR}=(\mathrm{ni} / \mathrm{N}) \times \mathbf{1 0 0} \%$

Keterangan :

KR : Kelimpahan relatif spesies

$\mathrm{Ni}$ : Jumlah individu spesies

$\mathrm{N}$ : Jumlah total individu

b. Kepadatan dihitung dengan formula

$$
\mathrm{D}=\frac{n}{A}
$$

Keterangan :

D : Kepadatan kerang kima (ind $/ \mathrm{m}^{2}$ )

n : Jumlah individu suatu spesies

A : Luas area pengamatan sampel $\left(\mathrm{m}^{2}\right)$

c. Pola sebaran jenis dihitung dengan mengacu pada ( Brown dan Zar, 1990),

$$
\mathbf{I d}=\mathbf{q} \frac{\sum \mathbf{n i}(\mathbf{n i}-\mathbf{1})}{\mathbf{N}(\mathbf{N}-\mathbf{1})}
$$

Keterangan :

Id : Indeks persebaran Morisita

q : Jumlah pengambilan sampel

ni : Jumlah individu pada pengambilan sampel ke-i

$\mathrm{N}$ : Jumlah total individu yang diperoleh

Tabel 1. Indeks dan pola persebaran Morista

Nilai Indeks

Pola Persebaran

Persebaran Morista

Id $>1 \quad$ Pola Sebaran

Id $=\mathbf{1}$

Berkelompok/agregrat

Id $<1$

Pola sebaran acak

Pola sebaran

teratur/seragam

Untuk menguji kebenaran nilai indeks di

atas, di gunakan uji Chi - Square dengan rumus berikut :

$$
X^{2}=\frac{\left(\sum X^{2}\right)}{N}-N
$$

Keterangan :

$x^{2}:$ chi square

$\mathrm{N}$ : Jumlah stasiun pengambilan

$\mathrm{N}$ : Jumlah individu yang di dapat di dalam plot

$\sum x^{2}:$ Jumlah individu yang di peroleh

Nilai Chi - Square dari perhitungan diatas di bandingkan dengan nilai Chi - Square tabel, dengan selang kepercayaan 95\%. Jika nilai $\mathrm{X}^{2}$ hitung lebih kecil dari $X^{2}$ tabel, maka di katakan bahwa bentuk penyebaran tidak berbeda nyata dengan acak.

\section{HASIL DAN PEMBAHASAN}

3.1. Kelimpahan Relatif Kerang Kima (Tridacnidae)

Hasil penelitian menemukan 5 jenis kima yaitu Tridacna squamosa, Tridacna crocea, Tridacna maxima, Tridacna gigas dan Hipoppus hipoppus dengan jumlah total individu 192. Kelimpahan relatif jenis kima yang ditemukan pada perairan Teluk Nitanghahai dapat dilihat pada gambar berikut.

Hasil penelitian menunjukan bahwa Kelimpahan relatif kerang kima berkisar antara 0,52\% - 38,54\%, jenis kima dengan kelimpahan relatif tinggi terdapat pada jenis Tridacna squamosa sebesar 38,54\% diikuti jenis Tridacna crocea sebesar $36,98 \%$ dan jenis Tridacna maxima sebesar $21,88 \%$, Tridacna gigas sebesar 2,08\% dan Hipoppus hipoppus sebesar 0,52\%.
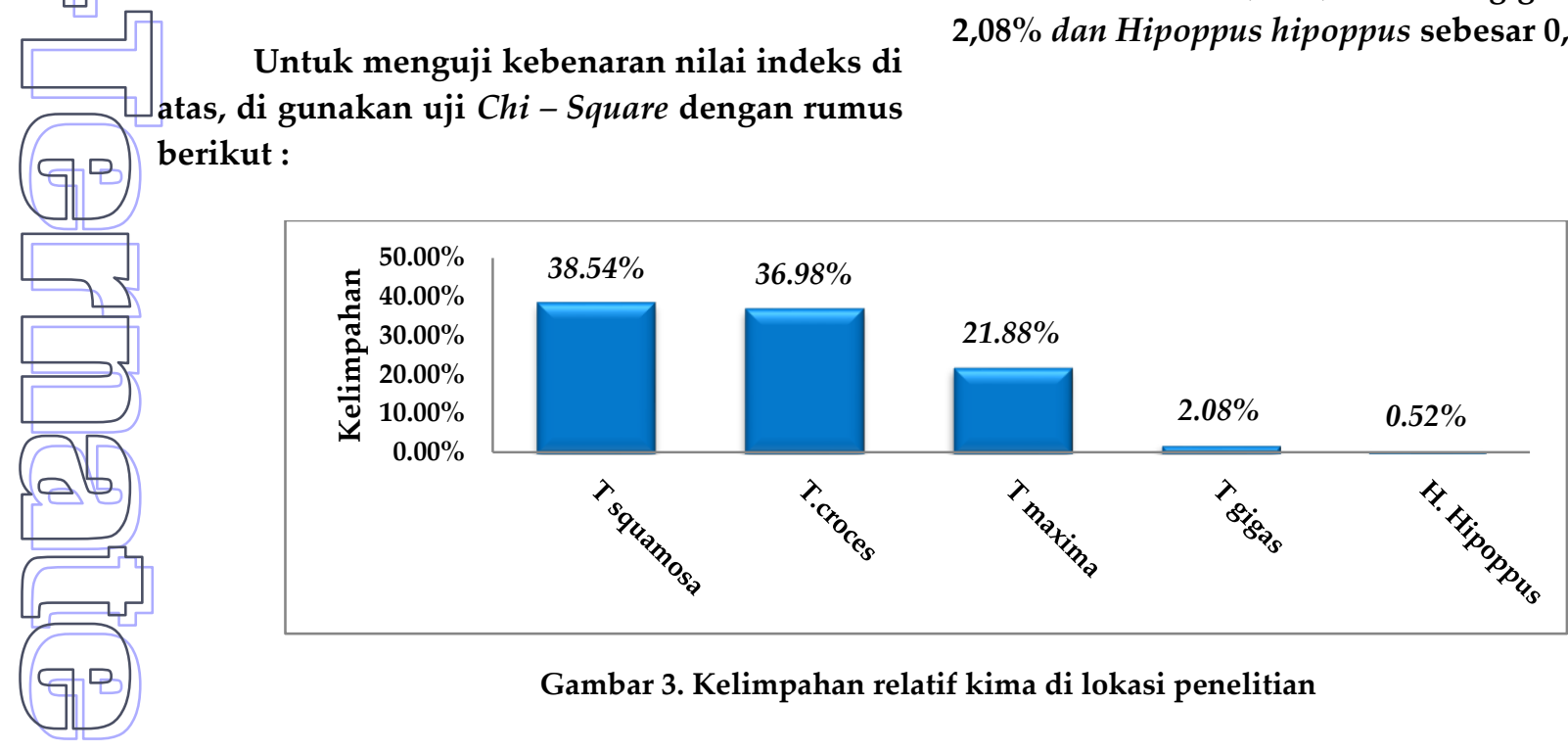

Gambar 3. Kelimpahan relatif kima di lokasi penelitian

Padilah dkk, 2015 menemukan 4 jenis kima di perairan Teluk Dalam Desa Malang
Rapat yaitu Tridacna squamosa, Tridacna crocea, Tridacna maxima dan Hippopus 
hippopus. kelimpahanrelatif terbesar adalah 3 Tridacna crocea $(73 \%)$, kemudian Tridacna squamosa (17\%), Tridacna maxima (6\%) dan Hippopus hipoppus ( $4 \%$ ).

Wakum dkk 2017, menemukan 8 jenis kima di tiga stasiun yang berbeda di perairan Amdui Distrik Batanta Selatan Kabupaten Raja Ampat yaitu Tridacna gigas,Tridacna maxima, Tridacnaderasa, Tridacna tevoroa, Tridacna crocea, Tridacna squamosa, Hippopus hippopus, dan H. Porcellanus dengan total jumlah individu 241.

Perbedaan jumlah kelimpahan jenis kima di beberapa lokasi diduga di sebabkan oleh faktor pengambilan kima secara langsung di alam oleh kebutuhan penduduk di sekitar pantai dan parameter kualitas perairan yang berbeda-beda pada setiap lokasi. Menurut Susiana, $d k k$ (2014) tingkat kelimpahan kerang kima di pengaruhi hubungan kualitas perairan (biologi, fisika, dan kimia). Parameter yang paling berpengaruh adalah kedalaman, salinitas, dan kecerahan.

3.2. Kepadatan Kima di Perairan Teluk Nitanghahai

Kepadatan jenis kima yang ditemukan di lokasi penelitian dapat dilihat pada Gambar 4.

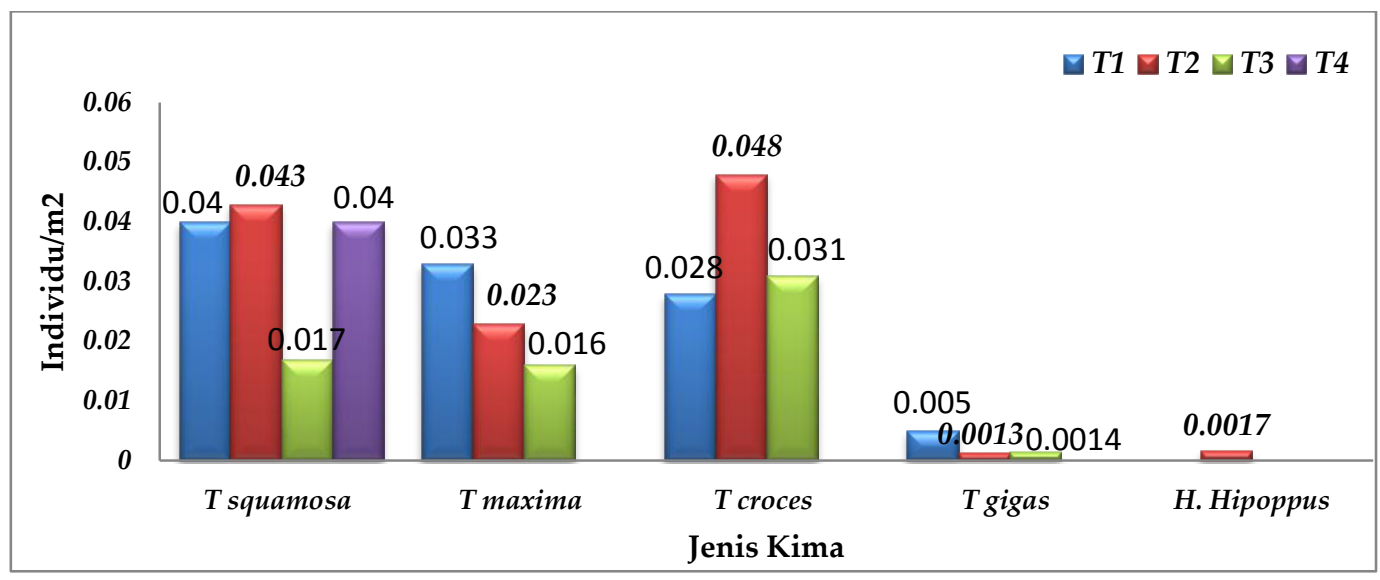

Gambar 4. Kepadatan kima (Tridacnidae) dilokasi penelitian

Secara keseluruhan kepadatan total kima di lokasi penelitian sebesar 0,3256 individu $/ \mathrm{m}^{2}$. Tinggi rendahnya kepadatan jenis kima pada setiap transek di lokasi penelitian diduga disebabkan faktor habitat yang cocok untuk kemampuan jenis-jenis kima beradaptasi dan bertahan hidup. Padila dkk., (2015) , Mengatakan bahwa substart merupakan salah satu parameter penting untuk bertahan hidup. Substrat kima biasanya pada daerah terumbu karang, pasir, dan pecahan karang.

\subsection{Pola Distribusi Kerang Kima}

Pola distribusi jenis kima di Perairan Teluk Nitanghahai dapat dilihat pada Tabel 2.

Tabel 2. Pola Distribusi Kima

\begin{tabular}{lcccccccc}
\hline \multicolumn{1}{c}{ Jenis } & $\mathrm{n}$ & \multicolumn{1}{c}{$\mathrm{N}$} & $\mathrm{Id}$ & $\mathrm{X}$ & $\mathrm{Db}$ & $\mathrm{X}$ & Kategori \\
\hline Tridacnasquamosa & 23 & 410 & 74 & 1.431 & 53.432 & 22 & 34 & Mengelompok \\
Tricana maxima & 23 & 138 & 42 & 1.282 & 33.571 & 22 & 34 & Mengelompok \\
Tridacna crocea & 23 & 473 & 71 & 1.86 & 82.225 & 22 & 34 & Mengelompok \\
Tridacna gigas & 23 & 6 & 4 & 3.833 & 30.5 & 22 & 34 & Acak \\
Hipoppus hipoppus & 23 & 1 & 1 & 0 & & 22 & 34 & Seragam \\
\hline
\end{tabular}

Berdasarkan Tabel 2, diketahui tiga jenis kima pola sebarannya mengelompok yaitu Tridacna squamosa, Tridacna maxima, dan Tridacna crocea. Pola distribusi mengelompok ini disebabkan oleh sifat spesies bergerombol atau adanya kesamaan habitat sehingga terjadi 
pengelompokan di tempat lain yang terdapat banyak bahan makanan. Menurut Odum (1993), menyatakan bahwa hal ini terjadi karena adanya pengumpulan individu sebagai strategis dalam menanggapi perubahan cuaca dan musim serta perubahan habitat dan proses reproduksi.

Sedangkan jenis kima yang pola distribusinya acak adalah Tridacna gigas, penyebaran secara acak terjadi dimana lingkungan sangat seragam dan terdapat kecenderungan untuk berkumpul. Menurut Indardjo dan Muslim (1997) dalam Riniatsih (2007), menyatakan bahwa penyebaran individu secara acak dapat terjadi jika habitat dalam keadaan seragam dan tidak ada kecendurungan dari organism tersebut untuk bersama-sama. Sedangkan Kima Jenis Hipoppus hipoppus pola penyebarannya seragam. Penyebaran seragam dapat terjadi dimana persaingan diantara individu sangat keras dan terdapat antagonis positif yang mendorong pembagian ruang yang sama.

Fenomena hidup berkelompok pada jenis-jenis kerang kima yang ditemukan mungkin disebabkan kerang kima tersebut memilih hidup pada habitat yang sesuai pada perairan baik dari segi factor fisik-kimia perairan maupun ketersediaan nutrisi. Suin (2002) juga menambah bahwa factor fisika dan kimia yang hampir merata pada suatu habitat serta tersedianya makanan bagi hewan yang hidup di dalamnya sangat menentukan hewan tersebut hidup berkelompok, acak, maupun normal.

\subsection{Parameter Kualitas Air}

Hasil pengukuran parameter kualitas air di lokasi penelitian dapat di lihat pada Tabel 3 . Marsuki et al (2013), menyatakan bahwa salinitas yang baik untuk kehidupan kima adalah 25 - 40 ppt, pH 7-9 dan kisaran suhu 25$30^{\circ} \mathrm{C}$.

Tabel 3. Parameter kualitas air

\begin{tabular}{clc}
\hline No & \multicolumn{1}{c}{ Parameter } & Nilai \\
\hline 1. & Suhu & $27-30^{\circ} \mathrm{C}$ \\
2. & pH & 8 \\
3. & Salinitas & $31-33 \mathrm{ppt}$ \\
\hline
\end{tabular}

\section{PENUTUP}

\subsection{Kesimpulan}

Berdasarkan hasil penelitian maka dapat disimpulkan bahwa :

1. Jenis-jenis Kima yang ditemukan di PerairanTeluk Nitanghahai adalah Tridacna squamosa, Tridacna maxima, Tridacna crocea, Tridacna gigas, dan Hipoppus hipoppus.

2. Kepadatan total Kima di Perairan Teluk Nitanghahai sebesar 0,3256individu/ $\mathrm{m}^{2}$ dimana kepadatan individu jenis kima tertinggi ditemukan pada jenisTridacna crocea sebesar 0,048 individu $/ \mathrm{m}^{2}$. Dan kepadatan terendah ditemukan pada jenis Hipoppus hipoppus sebesar 0,0017.

3. Pola sebaran jenis-jenis kima di perairan Teluk Nitanghahai terdiri dari mengelompok yaitu Tridacna squamosa, Tridacna crocea dan Tridacna maxima kemudian acak yaitu Tridacna gigasdan seragam pada Hipoppus hipoppus

\subsection{Saran}

Perlu dilakukan penelitian tentang pendugaan musim pemijahan kerang kima (Tridacnidae) di Teluk Nitanghahai Desa Morella.

\section{DAFTAR PUSTAKA}

Betay, Henny A, 2012. Jenis - Jenis Kima Dan Kelimpahannya Di Perairan Kepulauan Roon Kabupaten Teluk Wondama Papua Barat (Skripsi). Program Studi Manajemen Sumberdaya Perairan, Jurusan Perikanan, Fakultas Poeternakan Perikanan Dan Ilmu Kelautan, Universitas Negeri Papua, Manokwari.

CITES Management Authority Australia in litt. (2005). to the CITES Secretariat.

Marzuki, Ismail Dg., Sadarun, Baru., dan Palupi, Ratna Diyah 2013, Kondisi Terumbu Karang dan kelimpahan kima di perairan pulau Indo, Jurnal Mina Laut Indonesia, Vol. 01 No. 01, (61 - 72), ISSN : 2303-3959. 
Niartiningsih, Andi, 2012, Kima, Biota Laut Langka: Budidaya dan Konservasinya, Identitas Universitas Hasanuddin, Makassar.

Padilah, M, Arief Pratomo, dan Andi Zulfikar 2015. Pola sebaran kima di perairan teluk dalam desa Malang Rapat kecamatan Gunung Kijang, Kabupaten Bintan, Kepulauan Riau

Rani, Chair, 2003, Metode Pengukuran Dan Analisis Pola Spasial (Dispersi) Organisme Bentik, Jurnal Protein di Vol 19 Halaman 1351-1368.

Susiana, Andi N, Muhammad. A. A. 2014. Hubungan antara kesesuaian kualitas perairan dan kelimpahan kima (Tridacnidae) Di kepulauan Spermonde. Jurnal. Fakultas ilmu kelautan dan perikanan Universitas Hasanuddin Makassar

Suin, N,M. 2002, Pengukuran factor lingkungan biotic. Jurusan biologi FIMIPA.Universitas Andalans. Padang

Wakum, A., Muhammad Takdir dan Selfanie Talakua, 2014. Jenis - jenis kima dan kelimpahannya di perairan Amdui Distrik Batanta Selatan Kabupaten Raja Ampat. Jurnal Sumberdaya

Akuatik Indopasifik, Vol. 1 No. 1 Mei 2017

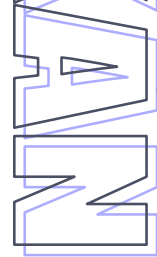

Yusuf, C., Ambariyanto, dan Hartati. 2009. Abundance of Tridacna (Family Tridacnidae) at Seribu Island And Manado Waters, Indonesia jurnal ilmu kelautan universitas diponegoro (UNDIP). Semarang. Vol. 14.

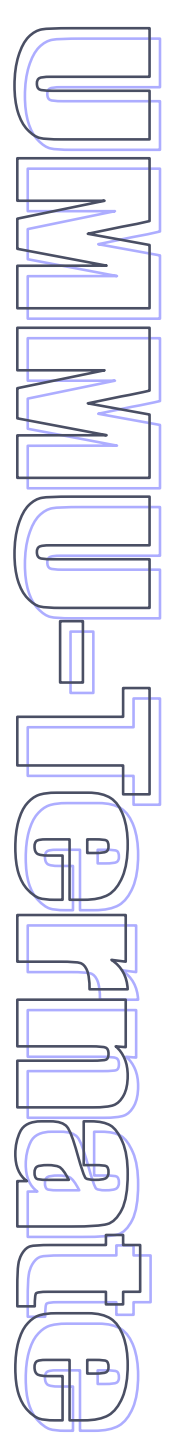

